\title{
PRECEDE and PROCEED Model on the Determinants of Teacher's Role in the Provision of Reproductive Health Education for Students with Mild Mental Retardation at School of Disability in Sleman, Yogyakarta
}

\author{
Putri Rahmasari'), Ismi Dwi Astuti Nurhaeni²), Endang Sutisna Sulaeman3) \\ ${ }^{1)}$ School of Midwifery, Aissyiah University, Yogyakarta \\ 2)Faculty of Social and Political Sciences, Universitas Sebelas Maret \\ 3)Faculty of Medicine, Universitas Sebelas Maret
}

\begin{abstract}
Background: Access to reproductive health information is lacking among students with mental retardation (MR). Teachers at the School of Disability have potentially important role in improving access to reproductive health information among students with MR. This study aimed to investigate the determinants of teachers role in the provision of reproductive health education for students with mild MR at School of Disability, in Sleman, Yogyakarta.

Subjects and Method: This was a qualitative study with phenomenology approach, conducted at School of Disability, Sleman, Yogyakarta. Key informants were selected by purposive sampling (i.e. criterion sampling), consisting 7 teachers of disability school, 5 personnels from the District Office of Education and Sport. PRECEED and PROCEDE model was used as a framework to identify the determinants under study. The data were collected by in-depth interview, observation, and document review. The data were analyzed by Miles and Hubberman method.

Results: The seven teachers have shown their good roles in the provision of reproductive health education. Factors that determined teachers role included knowledge, experience, attitude, subjective norms, perceived behavior control, external support, and availibility of resources. Weak perceived behavior control (e.g. perceived teacher's incompetence) and negative subjective norms (e.g. teaching about reproductive health was considered taboo by the community) of the teachers weakened the teachers role. Lack of educational media, substandard rooms, reproductive health materials that were unintegrated in the curriculum, weakened teachers intention to perform their roles.

Conclusion:Teachers at the school of disability in Sleman, Yogyakarta, have shown their good role in the provision of reproductive health education for students with mild MR. Knowledge, experience, attitude, subjective norms, perceived behavior control, external support, and availibility of resources, are important determinants of teachers role in the provision of reproductive health education.
\end{abstract}

Keywords: teachers role, school of disability, mental retardation, student

\section{Correspondence:}

Putri Rahmasari. School of Midwifery, 'Aissyiah University, Yogyakarta. Email: putrialzam@gmail.com.

\section{BACKGROUND}

Sexual rights are human rights related to sexuality. All adolescents have the right to obtain it, but this is often denied and ignored. As a result, $42 \%$ of HIV infections occur among adolescents, $10 \%$ of births from adolescent mothers around the world, and $23 \%$ of diseases due to pregnancy occur among adolescents, pregnancy is a major cause of death for young women aged 15 to 19 years around the world. Not only that, two-thirds of abortions around the world are carried out by young women and many are conducted unsafe. Another concern is 
that in some countries there are $48 \%$ forced first sexual intercourse experienced by young female adolesscents (International Planned and Parenthood and Federation / IPPF, 2012).

According to World Health Statistics 2013 (World Health Organization / WHO, 2013) around 16 million young women give birth every year. Babies who are born to adolescent mothers reach around $11 \%$ of all the births from around the world and 95\% of births occur in developing countries. In addition, it is estimated that three million unsafe abortions were carried out by young women. In Asia the estimated annual incidence of abortion is slightly higher in 2003 and 2008, from 25.9 million to 27.3 million. Southeast Asia has the highest abortion rate in 2008 (36 per 1,000). Whereas 60$65 \%$ of unsafe abortions occur in South Asia, Southeast Asia and West Asia (Guttmacher Institute, 2012). WHO estimates that in 2008, $12 \%$ of all maternal deaths in Asia are caused by unsafe abortions (WHO, 2011).

Another issue of adolescent reproductive health is the high number of HIV/ AIDS cases. According to Indonesia Basic Health Research (2010), groups of adolescents in Indonesia who had received new reproductive health education were $25.1 \%$ and in Yogyakarta reached 57.1\%. Meanwhile, comprehensive knowledge related to HIV and AIDS among adolescents in the age group of 15-24 years has only reached 11.4\%. From these data, it cannot be denied that adolescents are at the most high risk age group for contracting and transmitting HIV and AIDS. In order to control the spread and reduce the number of new cases of HIV/AIDS, special efforts need to be focused on groups of adolescents.

This study highlights more on adolescent girls. This is motivated by the vulnerability of sexual violence are more expe- rienced by women than men. This is indicated by reports of incidents of violence against women that have increased. Based on data from Forum for Handling Victims of Violence for Women and Children of Special Region of Yogyakarta in 2010, there were at least 1,305 cases of violence handled. While in 2011 it increased to 1,666 cases. Of these cases, $87 \%$ of the victims were women (Budi, 2013).

From the several adolescent reproductive health problems above, the availability of information and reproductive health sexuality education for adolescents is considered important. This can give an understanding of the risks of unsafe sexual behavior, ways to prevent unwanted pregnancies, transmission and prevention of HIV/AIDS, prevention of sexual violence, and information about physiological changes in adolescence. Extensive forms of socialization and solutions to reproductive health are essential for adolescents (Ministry of Women's Empowerment and Child Protection of Republic of Indonesia, 2010).

Quoted from Young People's Rights in IPPF (2012), the positive role of parents or guardians is very influential in the lives of adolescents. This includes providing guidance to adolescents about sexual and reproductive health. However, this guidance should not prevent them from accessing the information and services they need. This is because sexual development is a lifelong process that greatly affects adolescents, such as, growth and development, ways of thinking, emotions, and desires and needs of adolescents are also changed.

Quoted from the IPPF annual report (2013), $81 \%$ of IPPF clients are from the poor and vulnerable groups. People with disabilities are the most vulnerable and lack of reproductive health services regarding sexual and reproductive rights. They are more likely to experience sexual violence 
than their normal counterparts, while their reproductive and sexual health needs are often denied and ignored. This results in unclear information on health, education, sexual services and reproductive health for people with disabilities (IPPF, 2013).

Health education for non-disabled adolescents can be found in schools in the form of Adolescents Health Information Centers. Whereas, for disabled adolescents it is still difficult to obtain and need special skills according to the type of disability. The Family Planning Association in UK takes a comprehensive approach to training and supporting related to health and sexual and reproductive rights for people with disabilities. Parents, guardians of students, school, and health workers also need support in providing information about sexuality and reproductive health in ways that are understood by people with disabilities. Teachers also need to get training to be able to provide information about sexual and reproductive health (IPPF, 2013).

On December 13, 2006, the The United Nations General Assembly issued Resolution No.A/61/106 concerning the Convention on the Rights of Persons with Disabilities. The resolution contains the rights of persons with disabilities and states that they will take steps to guarantee the implementation of this convention. The Indonesian government has signed the convention. This shows the sincerity to respect, protect, fulfill and advance the rights of people with disabilities, including the right to get reproductive health education (Law of the Republic of Indonesia Number 19 of 2011).

The various regulations above regulate the fulfillment of the rights of poeple with disabilities including the right of reproductive health, but the implementation is not easy. According to the National Census Central Bureau of Statistics data
(2003), the number of people with disabilities in Indonesia was $0.7 \%$ of the population $(1,480,000$ people). Of these, around 66,610 school-age children (14.4\%) were enrolled in Schools of Disability. This means that $85.6 \%$ of people with disabilities are still in the community under the guidance and supervision of parents and families and in general have not gotten access to reproductive health services properly (Ministry of Health of Republic of Indonesia, 2010). Meanwhile, Kurniasariet al (2011) revealed that many people with disabilities had not been able to optimally access education and health services including reproductive health.

People with disabilities can be classified into several groups: blind, hearing loss/speech impaired, mentally retarded, disability, behavior disorders, Attention Deficit and Hyperactivity Disorder (ADHD), autism and multiple disabilities. Each has different characteristics, handling, and service. Schools of disability for mentally retarded student are in the third highest rank after mixed schools of disability and schools of disability for students with deafness/hearing impaired (Indonesian Ministry of Health, 2010). Therefore, this study further highlighted the types of disability in mental retardation.

The development of health protection programs for people with disabilities such as mental retardation needs to be given the attention of various parties to reduce and prevent health and psychosocial impacts which can result in conditions that are more severe and create burdens for families, communities, and the country. This cannot be done alone by the health sector, but requires a multisectoral approach and various disciplines. Therefore, cooperation with all related elements in the implementation is very necessary (Ministry of Health of the Republic of Indonesia, 2010). A study 
on source of access to sexuality information for people with disabilities (Oladunni, 2012), counseling of reproductive health from mothers intellectual disability people. (Kusumaningrum, 2012), health inequality problems in adults with intellectual disabilities (Greenwood \& Wilkinson, 2013), and support for married couples with intellecttual disabilities on reproductive rights (Llewellyn, 2013) have been done. Meanwhile, a study on how to provide reproductive health education for female adolescents with mental retardation from a teachers' perspective has not been specifically done.

Oladunni (2012) revealed that access to information on sexuality and management capacity for adolescents with disabilities are still poor. Adults with intellectual disabilities face various health inequalities and challenges in accessing health services. They have known a little about sexual health and how to optimize women's reproductive health services (Greenwood and Wilkinson, 2013). Therefore, counseling services and information on reproductive health should not only be available but also accessible and still treat them with respect, provide choices and responsibilities (Llewellyn, 2013).

Counseling by teachers in schools has a great potential to influence students' behavior and prevent the reproduction health impacts of students. According to Djati (2010), there were three strategies to address these challenges, namely the existence of family support, self-empowerment of groups of poeple with disabilities, and increasing publications. One of them is through discussion and other effective ways so that the information can be absorbed. This cannot be done by the teacher himself and requires a multisectoral approach from various disciplines. Therefore, cooperation with all related elements in its imple- mentation is very necessary (Ministry of Health of Repuplic of Indonesia, 2010).

Yogyakarta Special Region (DIY) is one of the provinces that have implemented inclusive education. Regional Regulation of Special Region of Yogyakarta No. 4 of 2012 states the protection and fulfillment of the rights of poeple with disabilities. In Reproductive Health section 54, it is also stated that persons with disabilities have the right and opportunity to obtain reproductive health education. Sleman Regency is one of the regency in the Special Region of Yogyakarta that has a good educational potential because $35 \%$ of colleges or academics are in this regency. In addition, Sleman has the highest number of special private schools for the Special Region of Yogyakarta (25 schools of disability).

Reproductive health conditions in Sleman tend to be worrying. This can be seen from the number of victims of sexual violence against women and children in 2015 increased by more than 100\% compared to 2014, from 51 victims to 116 victims (Women and Community Empowerment Agency, 2016). The high number of cases of sexual violence is caused by easily accessible IT developments, including pornography, but it is not balanced with the psychological and religious maturity of adolescents. Another trigger is the perception of the community that considers reproductive health education is taboo and not a preventive effort. From interviews at the two special private schools in Sleman regency, it was found that there were differrences in efforts and obstacles in reproductive health education. This prompted researchers to examine how the role of teachers in reproductive health education for female adolescent with mild mental retardation in schools of disability in Sleman. 
Journal of Health Promotion and Behavior (2016), 1(2): 110-120

https://doi.org/10.26911/thejhpb.2016.01.02.06

\section{SUBJECT AND METHOD}

This was a qualitative study with phenomenological approach. The sampling technique used was purposive sampling (i.e. criterion sampling). The criteria informants were schools of disability teachers who had attended reproductive health training from Education, Youth, and Sport Office of Special Region of Yogyakarta. Based on predetermined criteria, seven teacher informants from different schools of disability were obtained and five key informants from Education, Youth, and Sport Office of Special Region of Yogyakarta, Sleman Health Office and two community health center as representatives. Techniques for collecting data by in-depth interviews, observation and document review. The data were analyzed by Miles and Hubberman method.

\section{$\frac{\text { RESULTS }}{\text { 1. Predisposing Factors of Teacher's }}$ Roles}

a. Knowledge

The informant said that the changes experienced by adolescents with disabilities were the same as adolescents without disabilities. The difference with non-diffable and was the ability to understand the psychological conditions that were being experienced, thus affecting self-control and how to express those feelings. Self-control ability on psychological changes was considered weak. According to informants' observations, the difference in control between non-disabled and mentally retarded was the existence of shame and the ability to understand the consequences of actions of shame and the ability to understand the consequences of actions. For adolescents with mental retardation, this was not easy because it was influenced by cognitive factors.

The material presented included menstruation, personal hygiene, introduce- tion to reproductive organs, differences in organs and functions of reproductive organs between men and women, changes in puberty, the influence of puberty in relationships, human reproductive processes, and prevention of sexual abuse. The material that had not been delivered was about drugs and gender.

There were four informants who considered adolescent reproductive health material was not taboo and precisely important because students needed to know. Other informants considered it was taboo because environmental factors that assume sexual reproduction were not appropriate to be taugh.

\section{a. Subjective Norms}

Subjective norms consisted of internal and external aspects. The internal aspects were: (1) the informant believed that the material provided was important and good to convey; (2) reproductive health education for mental retardation must be given, (3) teachers' perceptions of taboo or not taboo regarding reproductive health material, and (4) informants assumed that it was not yet competent to deliver the material. While the external aspects believed by informants in providing reproductive health education included: (1) the negative judgment in the community about mental retardation had no libido, (2) taboo perceptions of the community, (3) taboo perceptions of parents, (4) taboo perceptions of students , (5) characteristics of mental retardation. This individual assessment will encourage someone to act and to behave.

\section{c. Attitude}

Teachers' positive attitude included the sense of caring of the teachers to provide reproductive health education because the material was considered necessary for mental retardation. The teacher thought that mentally retarded students needed to be given an early education as a preventive 
effort. Besides that, it was implied the attitude of the teacher who disagrees with the misconception of parents who considered mental retardation did not have libido. The negative attitude of the informants included the concerns if they were considered to be teaching bad things to students. The teacher was also worried if students did not fully understand the material given.

The more positive subjective norms that individuals believed would be directly proportional to the positive attitude they have. Contrary to negative subjective norms, this will provide a tendency for the provision of reproductive health education.

\section{b. Experience}

The youngest age was 38 and the oldest age was 51 years while the average age of the informant was 46 years old. The last informant education was 6 teachers from bachelor degree of special education (86\%) and 1 teacher from bachelor degree of Pancasila and Civic Education (14\%). The longest working period for special education teachers was 25 years, while the shortest working period was 8 years. Sources of information from informants regarding reproductive health education were obtained from reproductive health training (Technical Assistance for Reproductive Health), daily experience in meeting cases or problems, and personal experiences of teachers of adolescence.

\section{Enabling Factors of Teacher Role}

a. Counseling and school health unit room From the seven schools of disabilities, schools of disabilities 1 could show the counseling room. Other schools of disabilities stated that the counseling room becomes one with the school health unit room or done in the teacher's room. Based on observations in the school health unit room, it was found that all schools of disabilities already had a school health unit room, but in school of disabilities 2, school of disabilities 3, school of disabilities 4 and school of disabilities 5 the function was not as a a school health unit but for classrooms due to limited space.

b. Media, curriculum, and teaching materials

There were two media provided, namely reproductive health aprons and family reproductive health dolls. Of the seven schools of disabilities only school of disabilities 7 that had reproductive health aprons, while in Yogyakarta there were 3 schools of disabilities that had the reproductive health dolls of families. Informants used their own bodies or images in textbooks were then related to reproductive health material.

Reproductive health education for mentally retarded adolescents had not been integrated into the school curriculum. In its implementation, the teacher provided unstructured on certain subjects which were relevant to the theme. Teachers did not have teaching materials such as modules for reproductive health education guidelines. They used individual experience and material from training.

\section{Driving factors of the teacher role}

The factors that motivated teachers in providing Adolescent Reproductive Health education for mild mentally retarded adolescents include, (a) the existence of a Joint Ministerial Decree on the Counseling and Development of School Health Unit; (b) coaching and training teachers on reproductive health and School Health Unit to fulfill good human resources and meet the needs; (c) the absence of an internalising policy on reproductive health in the curriculum; (d) the contribution of the community health center in reproductive health education had not been evenly distributed; and (e) support from the principal and fellow teachers. 
Journal of Health Promotion and Behavior (2016), 1(2): 110-120

https://doi.org/10.26911/thejhpb.2016.01.02.06

\section{Teacher constraints in reproduc- tive health education}

The constraints of the teacher were (a) the limited number of human resources who had received training and were able to provide adolescent reproductive health material; (b) the difficulty of the teacher in delivering material in a language that was suitable for mentally retarded children; (c) the choice of approach or strategy, because in one class group consisted of different age backgrounds and levels of disability; (d) knowledge and collaboration with parents was still low regarding Adolescent Reproductive Health; and (e) community views (socio-cultural) that assumed that education of Adolescent Reproductive Health is taboo.

There were obstacles from external teachers: (a) the unavailability of health workers in the School of Disability such as doctors and psychologists to detect health problems; (b) the coordination mechanism with community health center was still limited to dental health checks and School Children Immunization Month, for handling Adolescent Reproductive Health yet; and (c) the attention of the health office and health center community was still low in Adolescent Reproductive Health education.

\section{DISCUSSION}

\section{Predisposing factors of teacher role}

a. Knowledge

The teacher's understanding of the changes that occur in mentally retarded young women among teachers was good. The teacher was able to explain the physical and psychological changes experienced by mentally retarded adolescents. The informant said that the fundamental physical changes experienced by young women were menstruation and then followed by secondary changes such as hair growth in the armpit and pubic area, pimples and breast growth. According to the teacher, physical changes, especially the menstrual experience in female adolescents with severe mental retardation, were said to be the same as non-disabled. However, the informant said that there were differences on growth of adolescents with severe mental retardation. The teacher did not explain the differences in detail.

The teacher's statement above was reinforced by the results of study that most young women with severe learning difficulties were on a normal developmental pathway, this was stated by Mel McMahon et al. (2008 in Yaacob et al, 2012). As for physical, emotional, psychological, and behavioral changes during the premenstrual phase, women with intellectual disabilities were just like women without intellectual disabilities (Lumbantobing, 2001).

Based on the information above, physical and psychological adolescents with mental retardation were the same as adolescents who did not experience disability. However, the physical weight level was different from non-disabled because there was a delay of 3-4 years for the menarche so that changes in secondary puberty would be too late.

Relating to the psychological changes experienced by adolescents with mental retardation was the attraction of the opposite sex. In general, adolescents with mental retardation experienced these changes as well as adolescents without mental retardation. However, control on the release of interest was considered as the most difficult. Besides the lack of knowledge of adolescents with mental retardation, they were also unable to distinguish between what was and could not be done. This was due to limited cognitive ability to analyze information. 
The results of the Swanson study (2015) stated that individuals with intellecttual disabilities such as mental retardation have constraints on the working memory capacity of the brain.

Teachers' understanding of the goals of reproductive health education varies from providing knowledge and building awareness of the importance of reproductive health, practicing healthy habits in order to maintain reproductive health, practicing independence, and having healthy relationships. In principle, the informant's objective was to equip adolescents comprehensively about knowledge, skills, and combined with values related to sexuality and reproductive health. In addition, students could make the right and responsible decisions related to their sexual and social life. The statement above was in accordance with the objectives of ICPD (1994), which allows adolescents to behave sexually positively and responsibly.

The material that had not been delivered was gender, human rights, HIV/ AIDS, and narcotics. Teacher's problem was the factor of students' inability to absorb the material, the giving strategy which was further addressed, alternative collaboration with parents could be considered. If the teacher's problem was the material mastery constraints, the teacher could increase the material capacity or work with the community health center or the private sector in accordance with the material expertise.

The presumtion of taboo was the perspective of teachers who felt awkward or unusual to deliver reproductive health material. Not all informants thought this material was taboo. The taboo presumption was more on the theme of the introduction of reproductive organs and human reproductive processes. The teacher was afraid to be delivered because in the teacher's envi- ronment and the general public the material was "indecent" so that it was not appropriate to be delivered. This was supported by the study of Kusumaningrum and Tanjung (2012), which stated that taboo factors become social problems that influence the behavior of providing reproductive health education.

\section{b. Subjective Norms}

The subjective norms of informants towards reproductive health education were separated into internal subjective norms and external subjective norms. Internal subjective norms included material beliefs that were important and good, the teacher's obligation to deliver the material, taboo or not assessment, and material mastery. While external subjective norms were factors outside the teacher, namely the presumption of mental retardation did not have libido even though they have, as well as taboo perceptions of the community among fellow teacher, parent, and student. What was often became a presumption was a taboo factor.

Reproductive health material which was taboo or not also influenced by knowledge, experience, and environment which in this case was a cultural background so that it formed a person's subjective norm. In TRA according to Martin Fishbein and Icek Ajzen (1980 in Priyoto, 2014) stated that subjective norms would encourage someone to be able to accept certain behaviors. Therefore, when the subjective norms of informants tend to encourage the provision of reproductive health education, it does not rule out the possibility that informants will follow it.

c. Attitude

The teacher's attitude towards reproductive health education was inseparable from the concept of subjective norms built on individuals. In this study the attitude of the informants was categorized as positive and 
negative attitudes. A positive attitude included the teacher's awareness of the need for adolescents with mental retardation to get reproductive health education. The teacher felt that mentally retarded students need to be educated earlier as a preventive effort. Besides that, it was implied that the teacher's attitude that disagree with the misconception of parents who consider that adolescents with mental retardation did not have libido. Another positive attitude was the teacher care to help mentally retarded students. The negative attitude of the informant included worry if it was considered to have taught things that were not good for students. Another concern was that when students did not understand it thoroughly and would do things they should not.

The more positive subjective norms that informants believed would be directly proportional to the positive attitude they have. Likewise, the opposite with negative subjective norms. It would eventually cause a tendency to act in supporting the provision of reproductive health education. According to Azwar (2005), if an individual had a positive attitude towards an object, he would be ready to help, pay attention, and did something that benefits the object. Conversely, if he had a negative attitude towards an object, then he would criticize, denounce, attack, and even destroy the object.

\section{d. Experience}

The informants' experiences included age, last education, length of work, and sources of reproductive health information obtained, in this matter including reproductive health technical guidance. In terms of the average age of 46 years, the last education of all informants had taken undergraduate degrees, while the length of work varies from 8 years to 25 years. All informants had also participated in reproductive health technical assistance from Education, Youth, and Sport Office of Special Region of Yogyakarta. The experience of the informants could be said to be good, but their experience of adolescent were reviewed by researchers.

Timmerman (2009) reported that personal beliefs and personal experiences of reproductive health education teachers also influence the practice of teaching their sexual education. Experience related to this case is how teachers got reproductive health education, whether from school, teachers, education in the family or through training.

\section{Enabling factors for teacher role}

All schools had a School Health Unit room, but the School Health Unit program was not running yet. School Health Unit room facilities were inadequate; the availability of space had a dual function as a classroom and the unavailability of adequate human resources. The counseling room was only available in one school. Reproductive health material had not yet been integrated into certain subjects either in documents or in class applications.

The implementation of reproductive health education in mentally retarded adolescents did not only depend on the teacher, but also on the contribution of the school and the local government to the provision and improvement of the quality of human resources, supporting facilities and expected curriculum. Besides that, health service providers could also contribute to the development of the School Health Unit program at the Schools of Disability. This was supported by the results of study namely parents, schools, and health care providers. All three had an important role in providing reproductive health information and services to promote sexual health and reproductive life (Mustapaa et al., 2015). 


\section{Driving factors of the teacher role}

The driving factors for the role of teachers and reproductive health education from Education, Youth, and Sport Office of Special Region of Yogyakarta were good, but from the Health Office and the Community Health Center were still lacking. In addition, support from shcool was still lacking, as efforts to raise partnerships with various related sectors had not been established.

Therefore, the Ministry of Health of the Republic of Indonesia (2011) stated that health education which was the part of health services would run well if it involved the school, family and community. These parties must be given special guidance in order to be able to carry out simple and useful actions according to the conditions and needs of mental retardation.

\section{Teacher constraints on reproduc- tive health education}

Teacher's constraints on reproductive health education could be elaborated as: a) the quality and availability of teachers who were able to provide reproductive health material and run a School Health Unit program were still lacking; b) the limited availability of representative media for the reproductive health education process; c) School Health Unit program in school of disability had not yet been implemented for mentally retarded students; d) the availability of School Health Unit infrastructure that supported the program was still lacking; e) there were no specific guidelines for the provision of reproductive health education for mentally retarded adolescents in School of Disability; f) the low attention of the district government to reproductive health services for mentally retarded students in School of Disability; g) cross-sectoral cooperation in dealing with reproductive health of adolescents with mental retardation in School of Disability was still not well established including the imple- mentation of School Health Unit; h) lack of knowledge of parents about reproductive health education for mentally retarded adolescents.

Some studies revealed that adolescents with disabilities had a lack access to sexual health information. This lack of access to information and poor sexual health knowledge among adolescents could be attributed to the low capacity of teachers and parents to teach sexual education, the absence of relevant curricula, teaching materials and other resources that could improve effective teaching and learning on sexual education (Oladunni, 2012).

\begin{tabular}{l}
\hline REFERENCE \\
\hline Azwar (2005). Penyusunan Skala Psikologi. \\
Yogyakarta: Pustaka Pelajar. \\
Greenwood NW, Wilkinson J (2013). Re- \\
view Article Sexual and Reproductive \\
Health Care for Women with Intel- \\
lectual Disabilities: A Primary Care \\
Perspective.Hindawi Publishing Cor- \\
poration International Journal of Fa- \\
mily Medicine 6(4):2472.
\end{tabular}

Guttmacher Institute (2008). Dalam Kesimpulan, Aborsi di Indonesia. New York: Guttmacher Institiut.

Guttmacher Institute (2012). In Brief, Facts on Abortion in Asia. New York: Guttmacher Institute.

International Planned and Parenthood and Federation (2012). Young People's Rights. www.ippf.org. Retrived on 20 January 2015.

International Planned and Parenthood and Federation (2013). Annual Performance Report 2013-2014. www.ippf.org. Diakses pada 20 Januari 2015.

Kementerian Kesehatan Republik Indonesia (2010). Riset Kesehatan Dasar 2010. Jakarta: Badan Penelitian dan Pengembangan Kesehatan RI. 
Journal of Health Promotion and Behavior (2016), 1(2): 110-120

https://doi.org/10.26911/thejhpb.2016.01.02.06

Kementerian Kesehatan Republik Indonesia (2010). Pedoman pelayanan kesehatan anak di sekolah luar biasa (SLB) bagi petugas kesehatan. Jakarta: Direktorat Bina Kesehatan Anak Kementerian Kesehatan RI.

Kurniasari TW, Propiona J, Marzuki MA (2011). Implementasi Hak Asasi Manusia di Indonesia: Hak Pendidikan dan Kesehatan bagi Anak Penyandang Disabilitas. Jakarta: LIPI.

Kusumaningrum, Tanjung AI (2012). Perilaku ibu terhadap pemberian pemahaman kesehatan reproduksi pada anak tuna grahita. Prosiding Seminar Nasional Dalam Rangka Dies Natalis UNDIP Ke-55 World Fit With Children. Fakultas Kesehatan Masyarakat Universitas Diponegoro Semarang, 6 Oktober 2012, Badan Penerbit Universitas Diponegoro.

Llewellyn G (2013). Parents with intellectual disability and their children: Advances in policy and practice. Journal of Policy and Practice in Intellectual Disabilities, 10(2): 82-85.

Lumbantobing (2006). Anak dengan Mental Terbelakang. Jakarta: Balai Penerbit FKUI.

Oladunni, Taiwo M(2012). Access to Sexuality Information among Adolescents with Disability. Life PsychologIA.
Priyoto. (2014). Teori sikap dan perilaku dalam kesehatan. Yogyakarta: Nuha Medika.

Swanson H, Lee (2015). Intelligence, working memory, and learning disabilities. Cognition, Intelligence, and Achievement:175-196.

Timmerman G (2009). Teaching skills and personal characteristics of sex education teachers. Teaching and Teacher Education 25. Elsevier: 500-506.

Undang-Undang Republik Indonesia Nomor 19 tahun 2011 tentang pengesahan convention on the right of persons with disabilities (Konvensi Mengenai Hak-Hak Penyandang Disabilitas).

World Health Organization (2011). Unsafe abortion: Global and regional estimates of the incidence of unsafe abortion and associated mortality in 2008 , sixth ed. Geneva: WHO.

Yaacob N, Nasira NM, Jalila SN, Ahmada R, Raidah NA, Rahima, Yusofa ANM (2012). Parents or caregivers' perception on menstrual care in individuals with down syndrome. Procedia-Social and Behavioral Sciences. Elsevier. 36: 128-136. 